\title{
Surgical management of raised intracranial pressure secondary to otogenic infection and venous sinus thrombosis
}

\author{
Rhian Bevan ${ }^{1}$ (i) $\cdot$ Chirag Patel $^{2} \cdot$ Imran Bhatti ${ }^{2} \cdot$ Johann te Water Naude $^{3} \cdot$ Frances Gibbon $^{3} \cdot$ Paul Leach $^{2}$
}

Received: 13 June 2019 / Accepted: 13 August 2019 / Published online: 23 August 2019

(C) The Author(s) 2019

\begin{abstract}
Purpose This study reviews paediatric patients with raised intracranial pressure as a result of venous sinus thrombosis secondary to otogenic mastoiditis, requiring admission to the paediatric neuroscience centre at the University Hospital Wales, Cardiff. The consensus regarding the management of otogenic hydrocephalus in the published literature is inconsistent, with a trend towards conservative over surgical management. We reviewed our management of this condition over a 9-year period especially with regard to ventriculo-peritoneal (VP) shunting.

Methods Analysis of a prospectively collected database of paediatric surgical patients was analysed and patients diagnosed with otogenic hydrocephalus from November 2010 to August 2018 were identified. Our data was compared with the published literature on this condition.

Results Eleven children, 7 males and 4 females, were diagnosed with otogenic hydrocephalus over the 9-year period. Five $(45.5 \%)$ required VP shunt insertion to manage their intracranial pressure and protect their vision. The remaining six patients (54.5\%) were managed medically.

Conclusions When children with mastoiditis and venous sinus thrombosis progress to having symptoms or signs of raised intracranial pressure, they should ideally be managed within a neuroscience centre. Of those children, almost half will need permanent cerebrospinal fluid diversion to protect their sight.
\end{abstract}

Keywords Otogenic hydrocephalus $\cdot$ Venous sinus thrombosis $\cdot$ VP shunt $\cdot$ Raised intracranial pressure

\section{Introduction}

Otogenic venous sinus thrombosis is a rare intracranial complication of mastoiditis and acute otitis media [1]. Its incidence has reduced significantly since the widespread use of contemporary antimicrobials [2]. However, it remains a serious complication of mastoiditis that needs prompt recognition and treatment to prevent further intracranial sequalae such as raised intracranial pressure (ICP). Patients who develop raised intracranial pressure (otogenic hydrocephalus) require

Rhian Bevan

bevanr8@cardiff.ac.uk

1 University Hospital of Wales College of Medicine, Cardiff, UK

2 Department of Paediatric Neurosurgery, University Hospital of Wales, Cardiff, UK

3 Department of Paediatric Neurology, University Hospital of Wales, Cardiff, UK specialist management to manage symptoms and prevent permanent loss of vision [3].

However, the consensus regarding the treatment of otogenic hydrocephalus in the published literature is inconsistent, with a trend towards conservative over surgical management [4]. The indications for conservative over surgical management of raised ICP also remain unclear from the published literature.

In this study, we review our case series of paediatric patients with otogenic hydrocephalus treated within a tertiary referral neuroscience centre. We compared our cohort to the published literature with regard to the need for cerebral spinal fluid (CSF) division.

\section{Methods}

Data on all patients with otogenic hydrocephalus treated at the University Hospital of Wales, Cardiff, UK, between November 2010 and August 2018 was collected. Data 
collected included patient demographics, clinical presentation, radiological findings, medical therapy and neurosurgical management. All patients were admitted jointly under paediatric neurology and paediatric neurosurgery.

\section{Results}

Eleven patients with otogenic hydrocephalus secondary to mastoiditis and venous sinus thrombosis were identified between November 2010 and August 2018 (Table 1). Of the 11 patients, 7 (64\%) were male and $4(36 \%)$ female with a mean age of 5.7 years at diagnosis. All 11 patients had symptoms of raised intracranial pressure. Eight out of $11(73 \%)$ patients had papilledema, 4/11 (36\%) had abducens nerve palsy, 4/11 (36\%) strabismus, (36\%) 4/11 visual field defects and 1/11 $(9 \%)$ seizures.

Seven (64\%) patients underwent lumbar puncture (LP) for diagnostic and symptomatic relief. Two out of 6 patients without a ventricular peritoneal (VP) shunt had a LP with a mean opening pressure of $45 \mathrm{~cm} \mathrm{H}_{2} 0$. Five out of five children who had a VP shunt had LP with a mean opening pressure of $58.2 \mathrm{~cm} \mathrm{H}_{2} 0$. Four patients $(36 \%)$ had intracranial pressure monitoring as part of their work up for otitic hydrocephalus. All four went on to have a VP shunts.

Overall a VP shunt was required in 5 patients $(45.5 \%)$ and the remaining six patients $(54.5 \%)$ had their raised ICP treated medically.

\section{Discussion}

Otitic hydrocephalus develops secondary to venous sinus thrombosis as a result of an inflammatory response to mastoiditis [5]. Following an otogenic infection, secondary inflammation may cause thrombophlebitis of the cerebral veins leading to venous sinus thrombosis. Due to its close anatomical location, the sigmoid sinus is the most commonly affected but local spread to adjacent dural sinuses may also occur [1]. The thrombosis disrupts both venous and CSF drainage in the brain resulting in raised ICP.

Table 1 Primary dataset. Summary of clinical and radiographic details of 11 children with otogenic hydrocephalus (November 2010 and August 2018 )

\begin{tabular}{|c|c|c|c|c|c|}
\hline $\begin{array}{l}\text { Patient } \\
\text { ID }\end{array}$ & $\begin{array}{l}\text { Age } \\
\text { (years) }\end{array}$ & $\begin{array}{l}\text { Radiological findings (affected } \\
\text { sinus) }\end{array}$ & Surgical treatment & $\begin{array}{l}\text { VP shunt } \\
\text { required }\end{array}$ & $\begin{array}{l}\text { Medical } \\
\text { treatment }\end{array}$ \\
\hline 1 & 5 & IJV & Mastoidectomy and myringotomy & $\mathrm{N}$ & $\begin{array}{l}\text { LMWH } \\
\text { IV Antibiotics }\end{array}$ \\
\hline 2 & 3 & SS & Mastoidectomy & $\mathrm{N}$ & $\begin{array}{l}\text { LMWH } \\
\text { IVAntibiotics }\end{array}$ \\
\hline 3 & 4 & SS, IJV & $\begin{array}{l}\text { Mastoidectomy } \\
\text { ICP monitoring }\end{array}$ & $\mathrm{Y}$ & $\begin{array}{l}\text { Rivoxaban } \\
\text { IVAntibiotics } \\
\text { Acetazolamide }\end{array}$ \\
\hline 4 & 4 & SS, TS, IJV & Mastoidectomy & $\mathrm{N}$ & $\begin{array}{l}\text { Rivoxaban } \\
\text { IVAntibiotics } \\
\text { Acetazolamide }\end{array}$ \\
\hline 5 & 5 & SS & $\begin{array}{l}\text { Mastoidectomy, } \\
\text { Myringotomy and craniotomy }\end{array}$ & $\mathrm{Y}$ & $\begin{array}{l}\text { Rivoxaban } \\
\text { IV Antibiotics } \\
\text { Acetazolamide }\end{array}$ \\
\hline 6 & 3 & TS & Mastoidectomy and myringotomy & $\mathrm{N}$ & $\begin{array}{l}\text { Rivoxaban } \\
\text { IVAntibiotics }\end{array}$ \\
\hline 7 & 4 & SS, TS, IJV & $\begin{array}{l}\text { Mastoidectomy } \\
\text { ICP monitoring }\end{array}$ & $\mathrm{Y}$ & $\begin{array}{l}\text { Rivoxaban } \\
\text { IVAntibiotics }\end{array}$ \\
\hline 8 & 9 & $\begin{array}{l}\text { TS } \\
\text { Epidural abscess }\end{array}$ & $\begin{array}{l}\text { Mastoidectomy, myringotomy and epidural abscess } \\
\text { drainage }\end{array}$ & $\mathrm{N}$ & $\begin{array}{l}\text { LMWH } \\
\text { IV Antibiotics } \\
\text { Acetazolamide }\end{array}$ \\
\hline 9 & 4 & SS, TS, IJV & $\begin{array}{l}\text { Mastoidectomy } \\
\text { ICP monitoring }\end{array}$ & $\mathrm{Y}$ & $\begin{array}{l}\text { LMWH } \\
\text { IVAntibiotics } \\
\text { Acetazolamide }\end{array}$ \\
\hline 10 & 11 & SS, TS, IJV & $\begin{array}{l}\text { Mastoidectomy } \\
\text { ICP monitoring } \\
\text { Optic nerve fenestration }\end{array}$ & $\mathrm{Y}$ & $\begin{array}{l}\text { Rivoxaban } \\
\text { IV Antibiotics } \\
\text { Acetazolamide }\end{array}$ \\
\hline 11 & 7 & SS, TS, & Mastoidectomy & $\mathrm{N}$ & $\begin{array}{l}\text { LMWH } \\
\text { IV Antibiotics }\end{array}$ \\
\hline
\end{tabular}

$I C P$, intracranial pressure; $L M W H$, low molecular weight heparin; SS, sigmoid sinus; $T S$, transverse sinus; IJV, internal jugular vein 
The vast majority of patients with mastoiditis remain in their local centres for treatment; however, in South Wales, patients with signs and symptoms of raised ICP are transferred to the paediatric neuroscience centre. Therefore, patients seen at our centre are those with suspected raised ICP secondary to otitic infection. These patients are jointly managed by paediatric neurosurgery and paediatric neurology.

The current published literature is sparse regarding the management of a raised ICP from otitic hydrocephalus. A literature review of 105 cases of otogenic sigmoid sinus thrombosis advocated conservative over neurosurgical management of raised ICP [4]. Ninety-four percent of these patients were treated medically; however, less than half of the patients $(46 / 105)$ were reported to have signs of raised ICP. Only $4 / 46(8.7 \%)$ of the patients with raised ICP went on to have a VP shunt. A smaller case series of otogenic sigmoid sinus thrombosis reported 4 out of 9 patients with otitic hydrocephalus [6]. Out of these 4 patients, $2(50 \%)$ required a VP shunt for management of a raised ICP. This is more in keeping with our experience.

There are a number a case report of children needing shunts for otitic hydrocephalus [7-11]. However, they do not reach any conclusions regarding the management of raised ICP or elucidate on the decision-making when to insert a VP shunt.

Our decision to insert a VP shunt is based solely on deteriorating vision in patients not responding to serial lumbar punctures (LPs). Serial lumbar punctures and ICP monitoring are useful adjuncts to the management and investigation of these patients, but neither are used in isolation to decide which patients undergo CSF diversion. The patients who underwent intracranial ICP monitoring all subsequently went on to have VP shunts in our series.

\section{Conclusions}

Ventriculo-peritoneal shunts are an effective treatment for patients with otitic hydrocephalus primarily to protect vision. From our experience and a review of the limited literature, up to $50 \%$ of these patients with signs and/or symptoms of raised ICP will require a VP shunt. Lumbar puncture and/or ICP monitoring in these children seem to be predictive with regard to needing a shunt. We feel that all patients with mastoiditis and venous sinus thrombosis who have signs or symptoms of raised intracranial pressure should be treated within a paediatric neurosciences centre.

\section{Compliance with ethical standards}

Conflict of interest The authors declare that they have no conflict of interest.

Open Access This article is distributed under the terms of the Creative Commons Attribution 4.0 International License (http:// creativecommons.org/licenses/by/4.0/), which permits unrestricted use, distribution, and reproduction in any medium, provided you give appropriate credit to the original author(s) and the source, provide a link to the Creative Commons license, and indicate if changes were made.

\section{References}

1. Go C, Bernstein JM, de Jong AL, Sulek M, Friedman EM (2000) Intracranial complications of acute mastoiditis. Int J Pediatr Otorhinolaryngol 52(2):143-148

2. Thompson PL, Gilbert RE, Long PF, Saxena S, Sharland M, Wong IC (2009) Effect of antibiotics for otitis media on mastoiditis in children: a retrospective cohort study using the United Kingdom general practice research database. Pediatrics 123(2):424-430

3. Manolidis S, Kutz JW (2005) Diagnosis and management of lateral sinus thrombosis. Otol Neurotol 26:1045-1051

4. Scherer A, Jea A (2017) Pediatric otogenic sigmoid sinus thrombosis: case report and literature reappraisal. Glob Pediatr Health 4:1-8

5. Smith JA, Danner CJ (2006) Complications of chronic otitis media and cholesteatoma. Otolaryngol Clin N Am 39(6):1237-1255

6. Bradley DT, Hashisaki GT, Mason JC (2002) Otogenic sigmoid sinus thrombosis: what is the role of anticoagulation. Laryngoscope 112(10): 1726-17-29

7. Viswanatha B (2010) Otitic hydrocephalus: a report of 2 cases. Ear Nose Throat J 89(7):E34-E37. https://doi.org/10.1177/ 014556131008900708

8. Velasco-Puyó P, Boronat-Guerrero S, del Toro-Riera M, VázquezMéndez E, Roig-Quilis M (2009) Intracranial hypertension associated with cerebral venous sinus thrombosis and mastoiditis. Two paediatic case reports. Rev Neurol 49(10):529-532

9. Kuczkowsi J, Dubaniewicz-Wybieralska M, Przewoźny T, Narożny MB (2006) Otitic hydrocephalus associated with lateral sinus thrombosis and acute mastoiditis in children. Am J Otolaryngol 70(10): 1817-1823

10. Brito AR, Vasconcelos MM, Domingues RC, Esteves L, Olivaes MC, Cruz LC, Herdy GV (2005) Pseudotumour cerebri secondary to dural sinus thrombosis: pediatric case report. Arg Neuropsiquiatr 63:697-700. https://doi.org/10.1590/S0004-282X2005000400029

11. Bari L, Choksi E, Roach EC (2005) Otitic hydrocephalus revisited. Arch Neurol 62:824-825

Publisher's note Springer Nature remains neutral with regard to jurisdictional claims in published maps and institutional affiliations. 